\begin{tabular}{|c|c|}
\hline International Journal of Current Research in \\
Biosciences and Plant Biology \\
\hline EXCELLENT \\
PUBLISHERS
\end{tabular}

\title{
Analysis of productivity of sloping land with solum shallow for maize plant development
}

\author{
Irwan Mado* \\ Faculty of Agriculture, Muhammadiyah University of Makassar, Jl. Sultan Alauddin No. 259 Makasssar 90221, Indonesia \\ ${ }^{*}$ Corresponding author
}

\begin{tabular}{|c|c|}
\hline Article Info & ABSTRACT \\
\hline $\begin{array}{l}\text { Date of Acceptance: } \\
\text { 10 December } 2018\end{array}$ & \multirow{3}{*}{$\begin{array}{l}\text { Utilization of land resources that slope and shallow solum need to get attention, so that } \\
\text { agricultural business can be profitable and sustainable. The more intensive the land use } \\
\text { for agriculture, the slope of land is currently experiencing quite heavy pressure, in } \\
\text { addition to the uncertain climate conditions and changes. On the one hand there are } \\
\text { demands of some communities for agricultural land to produce maximally and on the } \\
\text { other side there are also demands for land slope used wisely and sustainably, while the } \\
\text { ability and condition of society in the utilization of the land is quite diverse. This is a } \\
\text { matter of concern, because it will increase the area of land for the successful } \\
\text { development of agriculture. Thus a study is needed to model the specific dominant land } \\
\text { aspects of the site in the development of a crop species on a sloping and shallow solum } \\
\text { agricultural area. This research is aimed at: (1) to formulate productivity model of } \\
\text { shallow slopes and solum in corn cultivation area in Timbuseng Village, Pattallassang } \\
\text { District, Gowa regency of South Sulawesi; (2) Determine or map potential sites or areas } \\
\text { for corn plant development based on existing climatic conditions in the research area. } \\
\text { This research was conducted in Gowa District, South Sulawesi Province. Location } \\
\text { determination is done deliberately, because this area is generally sloped, has a shallow } \\
\text { solum and climatic conditions are changing. Soil sampling is done on each profile that } \\
\text { has been made, and there are } 32 \text { points of observation that is divided into } 17 \text { units of } \\
\text { land, then conducted a laboratory analysis to determine the physical, chemical and } \\
\text { biological properties of the soil. The land productivity model was established on the } \\
\text { basis of relevant land characteristics and influenced the production of maize, the range } \\
\text { of each land characteristic determined by regression analysis. Analysis of the } \\
\text { relationship between land characteristics with corn production using correlation } \\
\text { analysis. The results showed that the potential area for the development of maize in } \\
\text { Timbuseng Village, Pattallassang District, Gowa regency of South Sulawesi, is located } \\
\text { on o1, o5 and 14, with corn yields rather high (above } 6 \text { tons per hectare). }\end{array}$} \\
\hline Keywords & \\
\hline $\begin{array}{l}\text { Maize roductivity } \\
\text { Shallow solum } \\
\text { Slope } \\
\text { Zea mays }\end{array}$ & \\
\hline
\end{tabular}

\section{Introduction}

Land is one of the most potential natural resources to support agricultural development. Utilization of land resources for agricultural production needs to be adjusted to the agro-ecological conditions of the land, so that farming can be profitable and sustainable. Land for agriculture has been 
exploited intensively, consequently the land is currently experiencing considerable pressure. On the one hand, there is a demand for agricultural land to produce maximally and on the other side there are demands for productive land to be used wisely and sustainably, while the ability and condition of society in the land use is quite diverse. It is worth considering, as it can determine in the continuing efforts of agricultural development. To achieve successful agricultural development, a study is needed to model the site-specific dominant land aspects in an effort to develop a crop in an agricultural cultivation area.

Agricultural areas of each region can serve as a place or pockets of food production. To achieve this, spatial model or formulation is needed on integrated land use both in terms of biophysical conditions of land and economically, so that agricultural land in the area can produce optimally and sustainably (Doran et al., 2006). Land biophysical studies emphasize an understanding of the diversity of land properties, as it will determine the types of crops that can be developed or cultivated and a determinant of land productivity. Meanwhile, economic studies can provide direction on economic viability in the development of a particular commodity, including the development and management of land within a particular area (Rossiter 2004)

The combination of land biophysical conditions and the economic feasibility of the land, can determine the development potential of a particular plant species. The biophysical conditions of the land may reflect the value or characteristics of the land, this can be done with a parametric approach. The parametric system is a land classification system based on the influence or value of certain land features and then combines these effects to infer their potential levels (Sys et al., 1993). Then for economic feasibility, an income model was created to find out the economic conformity index (IKE) through $\mathrm{R} / \mathrm{C}$ ratio analysis.

A parametric system approach can be done to determine the model of a land productivity index. In such methods the influence of land or soil characteristics is individually assessed and then mathematically combined. The general structure of the parametric system is essentially the same, the combined effect of the individual factors is more multiplicative rather than additive, especially for soils of some excellent quality (Rayes, 2006). The productivity model or index can be defined as the physical productivity of a land for specific land use, aimed at calculating the contribution of certain factors that affect production. The productivity index is an example of a parametric system approach which is suitable for a detailed scale study, where productivity is strongly influenced by the topsoil (tillage). One of the productivity models used as the basis for this research is the productivity model proposed by Pierce et al. (1983).

The productivity model proposed by Pierce et al. (1983) is applied in Minnesota United States that has summer, cold, spring and autumn this is different from the conditions in Gowa Regency only summer and rain, so later the model is modified in accordance with the conditions that occurred at the location of research. This will certainly reflect site-specific outcomes.

The location-specific productivity model will determine the level of potential development of a particular land and for a particular crop including maize, in addition to realizing optimal land use, so that production is expected to increase wider unity, and economic benefits can be maximized (Luca and Carlucci, 2010). Thus it is necessary to classify the level of potential in the use of a land if used for a particular purpose in an area (Gabriel and Quemada, 2011). The existing land productivity model for corn crops is still general and does not reflect the specific model for a particular location; in addition, the assessment is based solely on the physical nature of the land, not yet based on its economic value aspect. In addition to the assessment of the productivity index, each land characteristic has the same level of importance or role, has not shown the interaction between parameters considered in assessing the potential of a land. Thus this does not reflect the potential level of land for corn plant development.

South Sulawesi has approximately 538 thousand hectares of farmland potential for corn development, but the average productivity of maize in South Sulawesi currently is 5,146 ton ha-1 (BPS of South Sulawesi Province, 2016) is still below the optimum productivity that can be achieved yield prediction). The optimal productivity of maize that 
can be achieved in some corn producing areas in Indonesia is 6 ton $\mathrm{ha}^{-1}$, according to DAICROS (daily crops simulation model) can reach 8.1 ton ha-1, and GCYI (good commercial yield under irrigation) reaches 9 ton $\mathrm{ha}^{-1}$ (Swastika et al., 2004).

Gowa regency is one of corn plantation development area with 38,711 ha of harvest area with productivity 5,676 ton ha-1 (Agriculture Office of Gowa Regency, 2015). Land use for the development of maize plants has a low potential level, caused by several factors that become obstacles or obstacles such as soil fertility $(\mathrm{pH}$, CEC, organic C, texture), soil depth, rock abundance and slopes. The area of maize development has a low compliance rate of about $42.72 \%$ and unsuitable $52.96 \%$ of the total area for corn crops $(168,692 \mathrm{ha})$, but the assessment of the potential level used is still general using broad coverage (Gusli et al., 2007).

The results of Syaifuddin's research (2008), suggested that land in Gowa Regency has good potential for the development of maize crops, but the potential level assessment is still general, not based on site-specific assessment or productivity model applied covering a wide range (small scale). In addition, the contribution or role of each land characteristic that becomes the valuation parameter has the same level of importance. Development of corn crops, mostly located in agricultural cultivation areas, the potential of maize production in Kabupaten Gowa is quite large, about 9.0 ton ha-1 per season, but the fact that occurred in the field only ranges from 4.56 to 6.16 tons ha-1. The low productivity of maize is due to the improper use of land resources due to land use planning errors, primarily related to sitespecific land-use requirements. To achieve optimal maize production in potential areas for maize, support of land characteristics / land quality, appropriate land management and local government policy support is required.

Timbuseng Village Pattallassang District Gowa Regency is an area that mostly has land conditions that slope and shallow solum. Topographical conditions in the region are generally wavy to hilly (15-30 percent) and low to moderate maize production levels, ie smaller than 5.4 to 7.2 ton ha-1 (Food Crop Agriculture Office of Gowa Regency,
2016). Besides, Timbuseng Village is in the rather rocky category, this resulted in the productivity of land for corn plant has not reached optimal in some areas. Thus the purpose of this study is to formulate a model of land productivity slopes with shallow solum, and determine the areas that have the potential for the development of corn crops.

\section{Materials and methods}

The research was conducted in Timbuseng Village, Pattallasang District, Gowa Regency, where the research location has topography of slope and solum which is shallow and slightly rocky. The materials used in this study include: composite and intact soil samples from each observation point, basic maps (corn production map, grid sample map, slope type, soil solum, land use, geology and others -other). In addition, a number of chemicals are required for analysis of soil samples in the laboratory and questionnaire materials. The tools used include, among others, the soil profile making device, Abney level, GPS (Global Positioning System), Scales, Munsell Soil Color Meter, pH meter, Hydrometer, scissors, manila cart, plastic bag, laboratory analysis tools, stationery and others.

Technique of collecting research data is based on observation points by using grid system. Data were collected through direct observation to the field through observation of soil profile and soil sampling in each soil profile coupled with interviews of corn farmers at the observation point location. In addition, secondary data in the form of climate data and other supporting data obtained from related institutions.

The research was conducted by using survey method consisting of several stages. (1) ground observation in the field is done at points of observation, determination of observation point is done by grid system, then at every point of observation made land profile or minipit. (2) soil sampling was performed on each soil profile or minipit for laboratory analysis, to find out: soil texture, fill weight, soil $\mathrm{pH}$, cation exchange capacity (KTK), water availability (gravimetric), nitrogen content, potassium, organic $\mathrm{C}$, water holding capacity (Water Holding Capacity) and others. The result or value of all the parameters of the soil, is converted into an adequacy value that 
has been made by Pierce et al. (1983), the value of the adequacy of each parameter is incorporated into the equation or productivity model, to obtain the actual productivity value (IPA). (3) validation in the field by determining actual corn production in the field (actual yield) determined by the ubinan method $2.5 \mathrm{~m} \mathrm{x} 2.5 \mathrm{~m}$ (Steel, 2011) using the equation as follows: Wc_ha $=1600 \times \mathrm{Wc \_ spl}$

Description: Wc_ha $=$ weight of maize $\left(\mathrm{kg} \mathrm{ha}^{-1}\right)$, Wc_spl $=$ weights of corn at $2.5 \mathrm{~m} \mathrm{x} 2.5 \mathrm{~m}, 1600=$ coefficient obtained from 10,000 / (2.5 x 2.5). (4) The model of land productivity is formulated based on the relevant land characteristics and affect the production of maize, the range of each land characteristic is determined by regression analysis. Analysis of the relationship between land characteristics with corn production using correlation analysis. The results of statistical analysis will determine the type and quantity of land potential determinants for the development of maize crops. (5) Potential land for the development of maize crops, based on the role or importance of each land characteristic and analysis of economic parameters of corn plant by using economic analysis $\mathrm{R} / \mathrm{C}$ ratio.

\section{Results and discussion}

Crop production is closely related to natural factors and human activities, particularly in relation to land management (Mueller et al., 2012). This is in line with that proposed by Bindraban et al. (2010), that the performance of the plant is strongly determined by several factors, such as the depth of solum, the slopes of land, the available water content and the nutrients found in the soil, and soil characteristics also greatly affect the productivity or yield of a plant. Maize crops will differ in growth and production under various soil conditions, due to diverse soil characteristics.

The observational data of the present study are provided along with figures (Fig. 1 - Fig. 4). The results showed that based on the land units that have been produced indicate that the yield of maize obtained in Timbuseng Village Pattallassang District Gowa District is in the range of 4.10 to 6.42 tons per hectare with an average of 5.18 tons per hectare (Table 1). Land units 01 and 14 have relatively high yields of maize (6.34 and 6.42 tonnes per hectare), this is due to the land conditions of these land units, having a flat slope (o to 3 percent) with shallow solum depths up to slightly deep (30 to $70 \mathrm{~cm}$ ). This is because the soil with the depth gives an opportunity for the roots of maize plants to develop properly, in addition nutrients and water are in sufficient quantities, so that the roots of corn plants can absorb nutrients and water as needed for its growth. This is consistent with that proposed by Djaenuddin, et al. (2003) and Mado, I., (2015), the depth of good soil solum for corn crops is more than $60 \mathrm{~cm}$. The results of this study are in line with the research of Timlin et al. (1998) and Calvino et al. (2003), the deeper solum provides higher maize yields than the shallow solum, thus the growth of maize plants proceeds well and ultimately gives optimal results.

The results of this study also show that the solum depth is about 30 to $60 \mathrm{~cm}$, with a flat to wavy (o to 15 per cent) area of land such as on unit 5 of land, yielding good maize (above 6 tons per hectare), this may occur because in such a field it will provide a longer chance for water to remain in the soil micro pores, besides the roots of corn plants are also not too deep so that the roots can use it well, and the growth of maize plants take place normally produce optimal maize.

A shallower solum depth and a slope above 15 percent yield low yields of corn. This can be seen in units of land 12, where the solum depth is only 23 $\mathrm{cm}$ and the slopes above 25 per cent give a low yield of maize (4.43 tons per hectare). This is due to the superficial solum, the roots of plants can not grow and develop well so that the roots of corn in the use of nutrients and water to be not optimal, this certainly affects the growth of the corn crop. Besides, water and nutrients that are in the condition of the slopes of land above 25 percent are easy to leach and the water rapidly seeps down, so it can not be stored in the soil micro pores, thus the water can not be bound by the grains, grains of land and became unavailable to corn crops.

Knowledge of water availability will help in water management to support the productivity of maize crops. Groundwater plays a very important role in regulating various processes in the soil on the ground-water interactions of plants. In general, plants require sufficient water availability, this is intended to support the entire process of plant growth and production. However, if the availability 
of water for corn is lacking or inadequate, because it has a shallow solum and a slope, then of course this affects the growth of the corn plant to provide optimal results.

\section{Observational Data P.74}

Units of land
Classification
Location
Location Latitude and Longitude
Micro Relief and Slope
Elevation
Ground moisture regime
Drainage Class
Land Use
Vegetation
Mother Material
Horizon identification
Corn Result
Corn variety
Age of corn harvest

$\begin{array}{ll}: 2 & \begin{array}{l}\text { Drainage Class } \\ \text { Land Usage } \\ \text { Vegetation } \\ \text { Typic Tropaquept }\end{array} \\ \text { Timbuseng Village, Pattallassang District } & \text { Mother Material } \\ : 0515 \text { ' } 12 \text { "LS } 119 \text { 33' } 17 \text { " BT } & \text { Horizon identifier } \\ : \text { Wavy and } 3 \text { to } 8 \text { percent } & \\ : 126 \mathrm{~m} \text { asl. } & \text { Corn Results } \\ : \text { Aquic } & \text { Corn variety } \\ : \text { Slow } & \text { Age of corn harvest } \\ : \text { Tackle } & \end{array}$

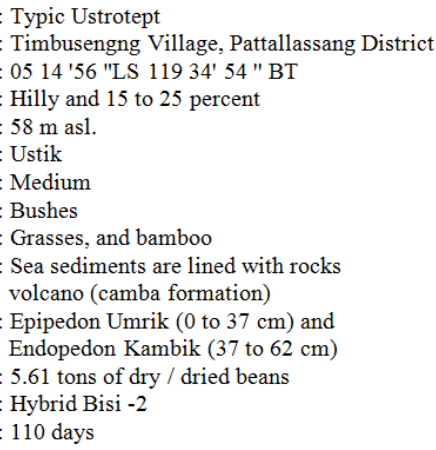

A $\quad 0-37 \mathrm{~cm}$; dark reddish brown (2.5 YR 3/4); clay; round globular structure, medium size, sufficient development; rather hard, loose, somewhat adherent and somewhat plastic; subtle and moderate roots; few fine pores; acid ( $\mathrm{pH} 4.5$ ); boundary and irregular.

B $\quad 37-62 \mathrm{~cm}$; dark reddish brown (2.5 YR 3/4); clay; round globular structure, medium size, sufficient development; rather hard, loose, somewhat adherent and somewhat plastic; medium and small roots; few fine pores; acid ( $\mathrm{pH} 4.4)$.

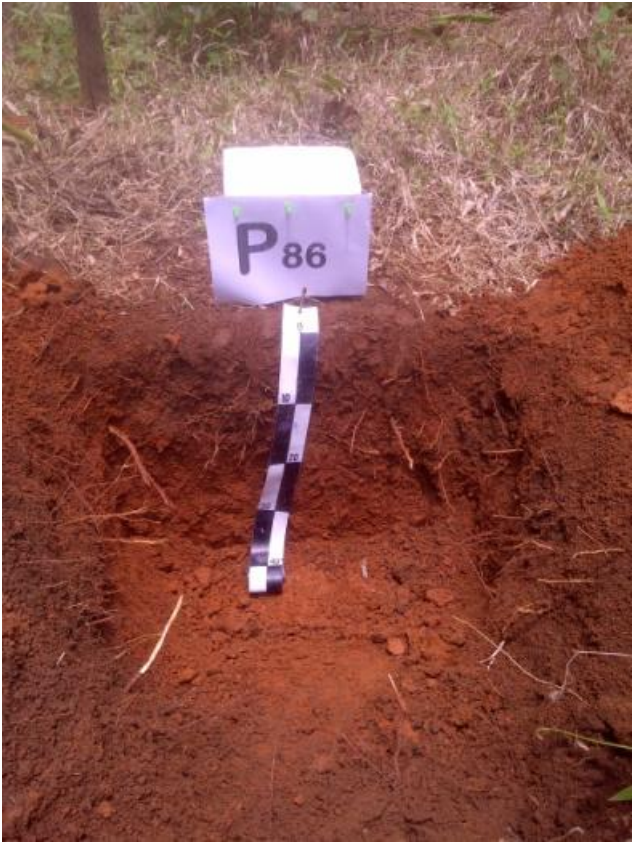

Fig. 2. Soil profile at observational data P.86
C $>62 \mathrm{~cm}$.

Fig. 1. Soil profile at observational data P.74

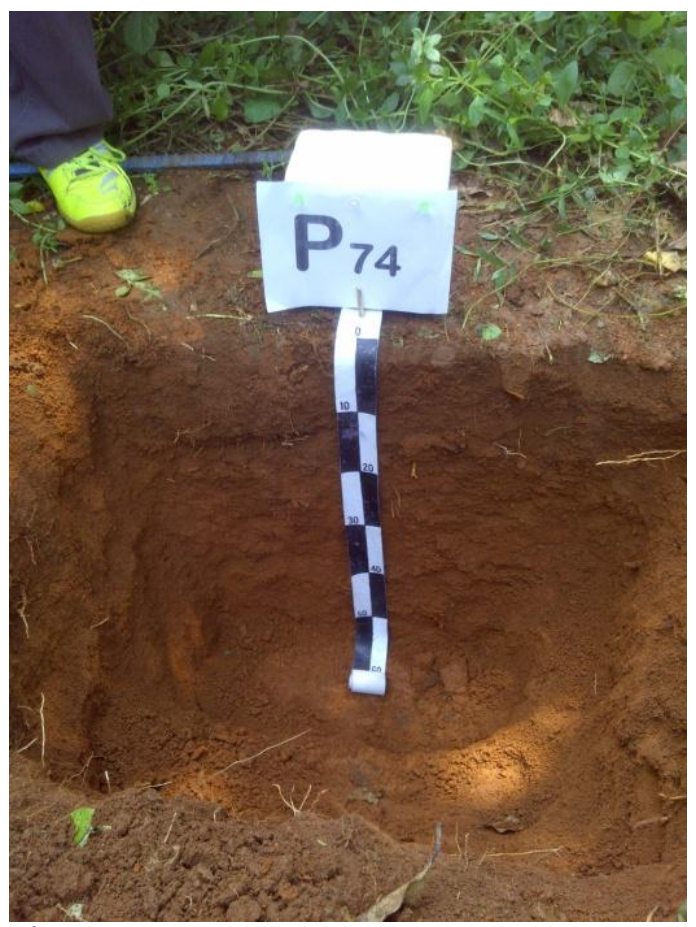

Irwan Mado (2019) / Analysis of productivity of sloping land with solum shallow for maize plant development 


\section{Observational Data P.93}

Units of land
Classification
Location
Location Latitude and Longitude
Micro Relief and Slope
Elevation
Ground moisture regime
Drainage Class
Land Use
Vegetation
Mother Material
Horizon identifier
Corn Result
Corn variety
Age of corn harvest

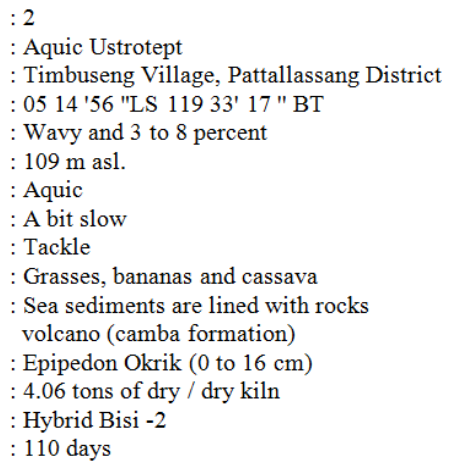

A $\quad 0-16 \mathrm{~cm}$; reddish black (10 YR 2.5/ 1); clay; redoximorphic or rusted, plain and ordinary appearance; rocky; angular clod structure, fine size, sufficient development; consistency rather hard, loose, somewhat adherent and somewhat plastic; little subtle roots; slightly acid ( $\mathrm{pH}$ 5.9); real boundary and choppy.

C $>16 \mathrm{~cm}$.

\section{Observational Data P.95}

Units of land
Classification
Location
Location Latitude and Longitude
Micro Relief and Slope
Elevation
Soil moisture regime
Drainage Class
Land Use
Vegetation
Mother Material
Horizon identifier
Corn Result
Corn variety
Age of corn harvest

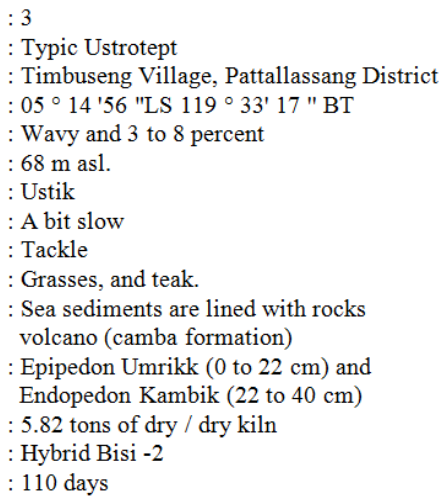

A $\quad 0-22 \mathrm{~cm}$; dark reddish brown (2.5 YR 2.5 / 2); clay; there are a few small stones; lumpy rounded structure, fine size, sufficient development; rather hard, loose, somewhat adherent and somewhat plastic; little subtle roots; few fine pores; acid ( $\mathrm{pH}$ 4.7); boundary and irregular.

B $22-40 \mathrm{~cm}$; dark reddish brown (2.5 YR 3/4); clay; lumpy structure slightly rounded, medium size, enough development; rather hard, loose, sticky and plastic; acid ( $\mathrm{pH}$ 5.0).

C $>40 \mathrm{~cm}$.

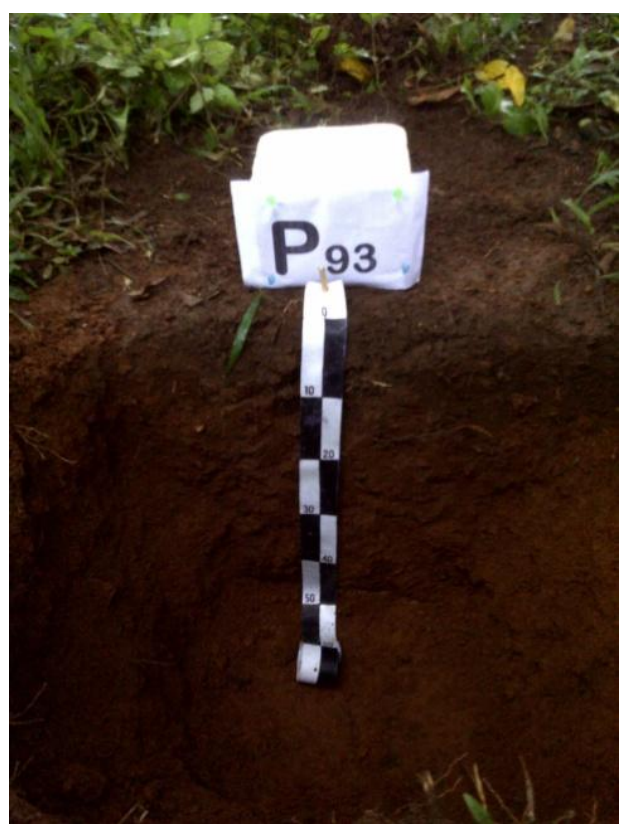

Fig. 3. Soil profile at observational data P.93

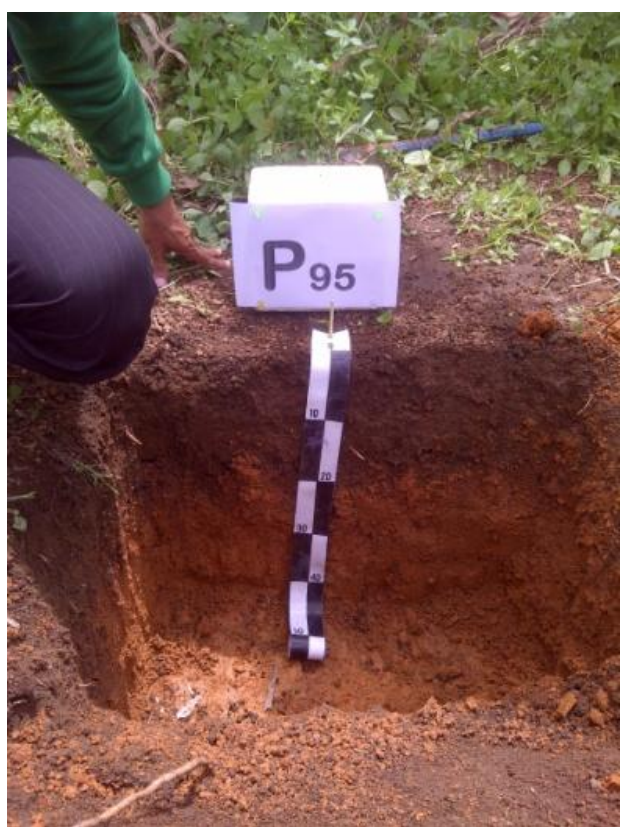

Fig. 4. Soil profile at observational point P.95

\section{Conclusion}

(1) The conclusion from the observation that has been done, show that the productivity model of slope with shallow solum is formulated based on land characteristic related to corn production, (2) Potential area of corn plant development in Timbuseng Village, Pattallassang District, Gowa regency of South Sulawesi, , 05 and 14 with corn yields rather high. 
Tab1e 1. Characterictics of land at each obervation point in Timbuseng Village, Patalassang District, Gowa Regency, South Sulawesi Province.

\begin{tabular}{|c|c|c|c|c|c|c|c|c|c|c|}
\hline No. & $\begin{array}{l}\text { Observation } \\
\text { point }\end{array}$ & $\begin{array}{l}\text { Depth of } \\
\text { Solum }(\mathrm{cm})\end{array}$ & $\begin{array}{l}\text { Slope } \\
(\%)\end{array}$ & $\begin{array}{l}\text { Water available } \\
\mathrm{cm} / \mathrm{cm}\end{array}$ & Texture & pH & $\begin{array}{l}\text { KTK } \\
\text { (me/10og) }\end{array}$ & $\begin{array}{l}\text { Organic } \\
\text { material }\end{array}$ & $\begin{array}{l}\text { K } \\
\text { element }\end{array}$ & $\begin{array}{l}\text { Result } \\
\text { (t/ha) }\end{array}$ \\
\hline 1 & B.68 & 64 & $>25$ & 0.20 & Le.P/Le.P & 6,1 & 38.51 & 2.78 & 0.94 & 5.61 \\
\hline 2 & B.70 & 68 & $08 \mathrm{~s} / \mathrm{d} 15$ & 0.18 & Le.P/Le & 5,0 & 34.68 & 1.84 & 0.94 & 5.24 \\
\hline 3 & B. 72 & 51 & $15 \mathrm{~s} / \mathrm{d} 25$ & 0.14 & Le./Le./Le. & 5,9 & 27.08 & 3.06 & 0.48 & 4.18 \\
\hline 4 & P.74 & 24 & o3 s/d o8 & 0.14 & Le.Li & 5,0 & 33.11 & 2.98 & 0,89 & 4.27 \\
\hline 5 & P.86 & 62 & $>25$ & 0.10 & Le.Li./Le.Li. & 4,5 & 20.28 & 2.31 & 0.22 & $5 \cdot 61$ \\
\hline 6 & B. 88 & 21 & $15 \mathrm{~s} / \mathrm{d} 25$ & 0.16 & Le. & 5,9 & 30.79 & $3 \cdot 31$ & 0.48 & 5.07 \\
\hline 7 & P.90 & 50 & o8 s/d 15 & 0.19 & Le.Li./Le.Li. & 5,6 & 22.87 & 3.49 & 0.19 & 6.07 \\
\hline 8 & P.93 & 16 & $03 \mathrm{~s} / \mathrm{d} \mathrm{o8}$ & 0.14 & Le.Li. & 5,9 & 24.25 & $3 \cdot 31$ & 0.32 & 4.06 \\
\hline 9 & P.95 & 40 & 03 s/d o8 & 0.11 & Li./Li. & 4,9 & 24.78 & 2.38 & 0.23 & 5.82 \\
\hline 10 & P.105 & 65 & $>25$ & 0.13 & Li./Li. & 4,6 & 24.82 & 2.10 & 0.34 & 5.18 \\
\hline 11 & B.107 & 89 & $\mathrm{o} \mathrm{s} / \mathrm{d} \mathrm{o} 3$ & 0.07 & Le./Li. & 6,4 & 31.31 & 2.27 & 0.73 & 6.52 \\
\hline 12 & P.109 & 44 & $>25$ & 0.27 & Le. & 6,1 & 29.46 & 4.12 & 0.51 & 5.24 \\
\hline 13 & P.111 & 41 & $>25$ & 0.15 & Le. & 5,8 & 38.42 & 1.10 & 1.35 & 5.17 \\
\hline 14 & P.121 & 68 & $08 \mathrm{~s} / \mathrm{d} 15$ & 0.11 & Le./Le.Li.P & 5,9 & 32.29 & 2.00 & 0.70 & 5.61 \\
\hline 15 & P.123 & 56 & $08 \mathrm{~s} / \mathrm{d} 15$ & 0.17 & Li./Li. & 4,7 & 21.84 & 2.17 & 0.23 & 5.24 \\
\hline 16 & B.125 & 70 & o s/d o3 & 0.18 & Le./Le.P & 5,9 & 38.66 & 1.30 & 0.49 & 6.45 \\
\hline 17 & P.127 & 35 & $03 \mathrm{~s} / \mathrm{d} 08$ & 0.04 & Le.Li & 5,7 & 23.14 & 3.47 & 0.25 & 4.15 \\
\hline 18 & P.129 & 18 & $15 \mathrm{~s} / \mathrm{d} 25$ & 0.15 & Le. & 6,1 & 37.26 & 4.57 & 0.86 & 4.58 \\
\hline 19 & P.131 & 30 & o s/d o3 & 0.22 & Li./Le.Li & 5,0 & 21.97 & 2.58 & 0.21 & 6.42 \\
\hline 20 & P.138 & 51 & $>25$ & 0.12 & Le.Li & 4,6 & 21.42 & 3.41 & 0.24 & 4.10 \\
\hline 21 & P.142 & 51 & o8 s/d 15 & 0.13 & Le.Li.D/Li & 4,7 & 22.79 & 3.06 & 0.17 & 6.63 \\
\hline 22 & P.144 & 22 & $>25$ & 0.16 & Li.P/Li.P/Li.P & 5,9 & 22.62 & 2.95 & 0.19 & 5.14 \\
\hline 23 & P.146 & 61 & $15 \mathrm{~s} / \mathrm{d} 25$ & 0.14 & Li./Li. & 5,2 & $35 \cdot 32$ & 2.01 & 0.22 & 6.34 \\
\hline 24 & B.155 & 41 & o8 s/d 15 & 0.04 & Le.P & 5,7 & 37.66 & 0.69 & 0.73 & 5.17 \\
\hline 25 & P.157 & 46 & $15 \mathrm{~s} / \mathrm{d} 25$ & 0.21 & Li./Li. & 5,1 & 23.84 & 2.50 & 0.13 & 4.45 \\
\hline 26 & P.159 & 66 & 15 sd 25 & 0.14 & Le.Li./Li. & 5,2 & 23.33 & 2.05 & 0.19 & 5.10 \\
\hline 27 & P.161 & 23 & $>25$ & 0.19 & Le.P & 5,9 & 33.14 & 1.72 & 0.91 & 4.15 \\
\hline 28 & P.163 & 53 & o s/d o3 & 0.11 & Li./Li. & 5,2 & 24.26 & 2.58 & 0.14 & $5 \cdot 34$ \\
\hline 29 & P.165 & 52 & o s/d o3 & 0.12 & Le./Li. & 5,6 & 21.26 & 3.26 & 0.40 & 6.06 \\
\hline 30 & B.176 & 71 & $15 \mathrm{~s} / \mathrm{d} 25$ & 0.12 & Le./Le.P & 6,1 & 59.81 & 0.56 & 0.92 & 6.53 \\
\hline 31 & P.178 & 24 & $>25$ & 0.16 & Le.P. & 5,9 & 48.62 & 1.07 & 1.08 & 4.01 \\
\hline 32 & P.184 & 52 & o s/d o3 & 0.18 & Le./Li. & 6,3 & 31.40 & 2.07 & 0.20 & 5.24 \\
\hline
\end{tabular}




\section{Suggestion}

(1) The formulation of land productivity models for the development of corn crops should consider adding some land characteristics such as; drainage, rusty content contained in the soil, (2) Areas that have low development potential, should be done to change the type of plant, or used as pasture for cattle grazing.

\section{Conflict of interest statement}

Author declares that there is no conflict of interest.

\section{Acknowledgement}

The author would like to thank DRPM Ristekdikti as the party who funded this research.

\section{References}

Doran, J.W., Stamatiadis, S.I., Heberem, J. 2002. Preface: Soil health as an indicator of sustainable management. Agric. Ecosyst. Environ. 88, 107-110.
Gabriel, J.L., Quemada, M., 2011. Replacing bare fallow with cover crops in a maize cropping system: Yield, N uptake and fertiliser fate. Eur. J. Agron. 34, 133-143.

Luca, S., Carlucci, M., 2010. Estimating land degradation risk for agriculture in Italy using an indirect approach. J. Ecol. Econ. 69, 511518.

Mueller, N.D., Gerber, J.S., Johnston, M., Ray, D.K., Ramankutty, N., Foley, J.A., 2012. Closing yield gaps through nutrient and water management. Nature. 490, 254-257.

Pierce, F.J., W.C., Dowdy, R.H., Graham, W.A.P., 1983. Productivity of soil: Assessing long term changes due to erosion. J. Soil Water Conserv. $38,39-44$.

Rossiter, D.G., 1994. Geographical Information System (GIS). Lecture Notes: 'Land Evaluation', College of Agriculture and Life Sciences. Department of Soil, Crop and Atmospheric Sciences, Cornell University.

Sys, C., Van Ranst., Debaveye, I., 1993. Land evaluation, part III Crop requirements. Agriculture publication, Brussel-Belgium.

\section{How to cite this article:}

Mado, I., 2019. Analysis of productivity of sloping land with solum shallow for maize plant development. Int. J. Curr. Res. Biosci. Plant Biol. 6(1), 29-36. doi: https://doi.org/10.20546/ijcrbp.2019.601.005 